\title{
Factors Impacting Customer Loyalty to LienVietPostBank, Binh Thuan Province
}

\author{
Dong Ngoc Vuong Thai ${ }^{1}$, Nguyen Quoc Nghi ${ }^{2}$ \\ ${ }^{1}$ Phan Thiet University, ${ }^{2}$ Can Tho University, Vietnam \\ Corresponding Author: Dong Ngoc Vuong Thai
}

\begin{abstract}
The objective of this study is to determine factors affecting the loyalty of individual customers to LienVietPostBank Binh Thuan. Research data are collected from 395 individual customers who are recently using services at LienVietPostBank Binh Thuan. The study applies exploratory factor analysis and multivariate linear regression. The research results have proved that positive affecting factors to the loyalty of individual customers to LienVietPostBank Binh Thuan are reliability, responsiveness, assurance, sympathy, tangible facilities, the reasonableness of service charges, social responsibility, and customer satisfaction. In which, satisfaction and sympathy have the most influence on the loyalty of individual customers to LienVietPostBank Binh Thuan.
\end{abstract}

Keywords: Loyalty, individual customer, service quality, LienVietPostBank Binh Thuan

\section{PROBLEM STATEMENT}

Currently, the competition among financial service providers in the commercial banking system is increasingly fierce and fierce. In the future, the penetration of $100 \%$ foreign-owned banks makes the competition between banks even more serious. In this foreground, customer retention becomes necessary for commercial banks. A stable customer source brings stable revenue and profit, creating safety for the bank's operations. Therefore, more and more banks are concerned about building customer loyalty strategies.

Like many other commercial banks, the service activities of the
LienVietPostBank system, especially LienVietPostBank Binh Thuan have constantly improved and developed into global integration. The bank continuously enhances services to best meet the needs of customers. LienVietPostBank Binh Thuan has strived to improve the professional qualifications for employees, update financial e-services to catch up with the technology trend. However, many commercial banks are operating in Binh Thuan Province recently, the retail activities at LienVietPostBank Binh Thuan have not achieved positive results and still face difficulties. Besides, the bank has a small scale and enters the market later than other commercial banks. Maintaining existing customers and finding potential ones are difficult. Therefore, it is challenging for the bank, putting pressure on its management board to maintain the existing customer base and find new customers to compete with other local competitors.

\section{THEORETICAL FRAMEWORK AND RESEARCH MODEL}

Loyalty is a deep commitment of a customer to re-purchase or re-visit a preferred product/service in the future, thereby causing the repetition in brand or reordering, despite environmental influences or marketing efforts may lead to behavior changes (Oliver, 2000). Customers are called brand loyal when they tend to buy many products of a certain brand and repeat their purchases (Chaudhuri \& Holbrook, 2001). Loyalty reflects the attitude of 
customers, if they trust and have an products of that brand to others (Yoo et al., 2000). Loyalty behavior focuses on the customer's value to the brand (Schultz \& Bailey, 2000). Loyalty attitude includes 3 components: (1) customer knowledge and belief, (2) customer perception and evaluation, (3) customer action orientation and passivity. Customer loyalty is measured as an attitude (brand preference, purchase intention, or commitment).

After reviewing both domestic and foreign studies on customer loyalty, the impression on a brand, they prefer buying authors apply group discussions (qualitative research) with customers who are using services at LienVietPostBank Binh Thuan. The study then proposes a research model including nine groups of influencing factors to customer loyalty: trust, responsiveness, assurance, sympathy, switching cost, perceived value, tangible means, social responsibility, and customer satisfaction. The research model is as below.

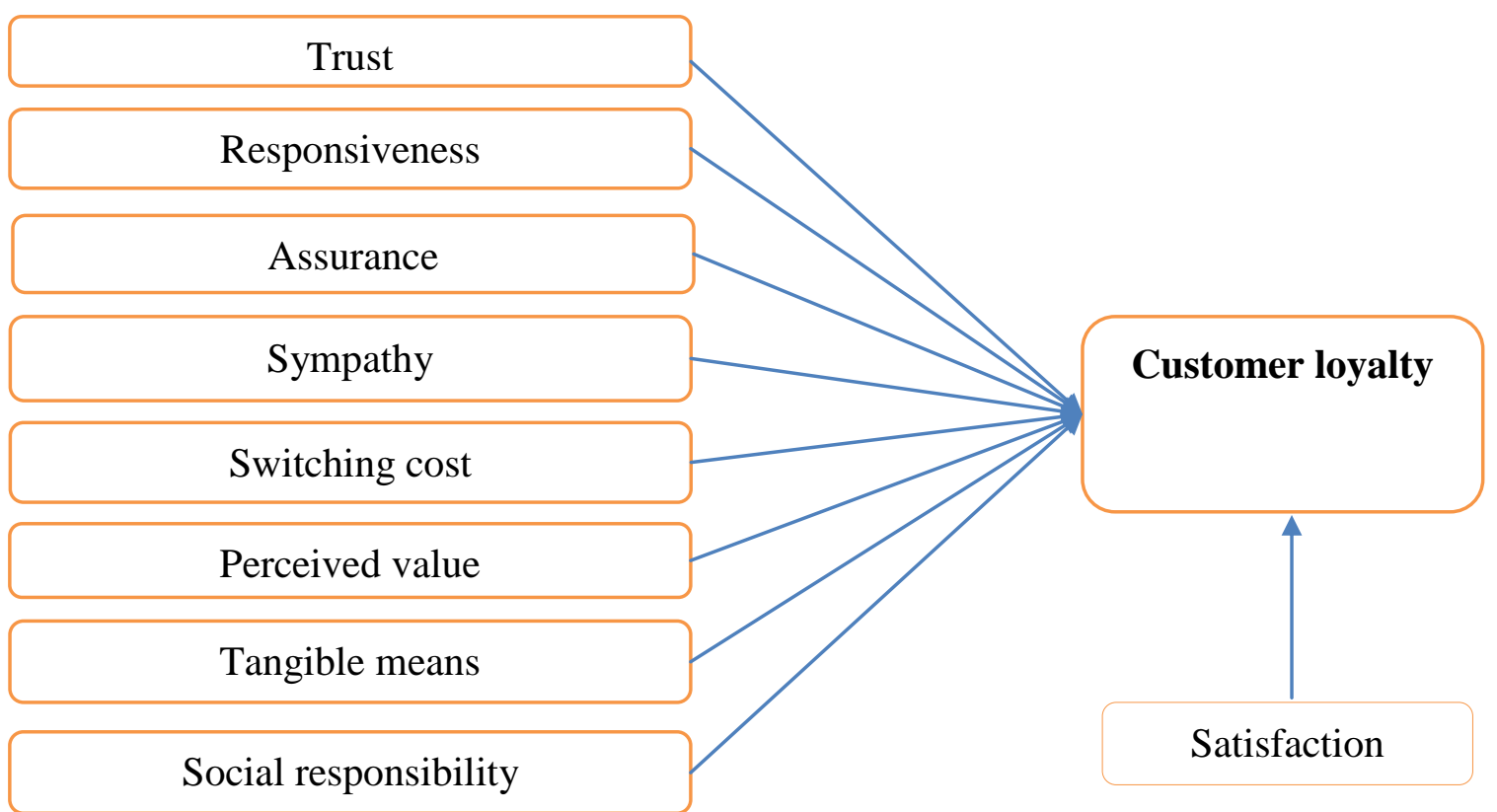

Figure 1: Proposed research model

The research hypotheses are suggested as follows: H1: Trust positively affects customer loyalty. H2: Responsiveness positively impacts customer loyalty. H3: Assurance positively affects customer loyalty. H4: Sympathy beneficially affects customer loyalty. H5: Switching cost positively influences customer loyalty. H6: Perceived value positively affects customer loyalty. H7: Tangible means positively impact customer loyalty. H8: Social responsibility beneficially influences customer loyalty. H9: Satisfaction positively affects customer loyalty.

\begin{tabular}{|c|c|c|c|}
\hline Factor & Description & Sign & Scale \\
\hline \multirow[t]{5}{*}{ Trust } & Customers feel confident in the bank's reputation. & $\mathrm{TR}_{1}$ & Likert 1-5 \\
\hline & The bank provides the services following the time as committed. & $\mathrm{TR}_{2}$ & Likert 1-5 \\
\hline & Transactions are always done quickly and accurately from the beginning. & $\mathrm{TR}_{3}$ & Likert 1-5 \\
\hline & Customers always feel safe making transactions with the bank. & $\mathrm{TR}_{4}$ & Likert 1-5 \\
\hline & The bank keeps customers' information confidential. & $\mathrm{AS}_{1}$ & Likert 1-5 \\
\hline \multirow[t]{4}{*}{ Assurance } & $\begin{array}{l}\text { The staff responds to customers quickly despite the high frequency of customers at the same } \\
\text { time. }\end{array}$ & $\mathrm{AS}_{2}$ & Likert 1-5 \\
\hline & $\begin{array}{l}\text { The bank has a flexible pricing policy, competitive interest rates, and a reasonable transaction } \\
\text { fee schedule. }\end{array}$ & $\mathrm{AS}_{3}$ & Likert 1-5 \\
\hline & The staff gets the service done quickly. & $\mathrm{AS}_{4}$ & Likert 1-5 \\
\hline & The staff does not annoy customers. & $\mathrm{AS}_{5}$ & Likert 1-5 \\
\hline
\end{tabular}




\begin{tabular}{|c|c|c|c|}
\hline \multicolumn{4}{|c|}{ Table 1 Continued... } \\
\hline \multirow{6}{*}{ Responsiveness } & Quick payment time. & $\mathrm{RE}_{1}$ & Likert 1-5 \\
\hline & Wide range of products. & $\mathrm{RE}_{2}$ & Likert 1-5 \\
\hline & Simple and fast transaction process. & $\mathrm{RE}_{3}$ & Likert 1-5 \\
\hline & The service staff serves quickly and promptly. & $\mathrm{RE}_{4}$ & Likert 1-5 \\
\hline & Good relationships with other banks. & $\mathrm{RE}_{5}$ & Likert 1-5 \\
\hline & The staff handles complaints quickly and appropriately. & $\mathrm{RE}_{6}$ & Likert 1-5 \\
\hline \multirow[t]{4}{*}{ Sympathy } & The bank takes care of every customer. & $\mathrm{SY}_{1}$ & Likert 1-5 \\
\hline & The staff is active in taking care of customers' difficulties. & $\mathrm{SY}_{2}$ & Likert 1-5 \\
\hline & The bank pays attention to customers' needs. & $\mathrm{SY}_{3}$ & Likert 1-5 \\
\hline & Good promotion and customer care programs. & $\mathrm{SY}_{4}$ & Likert 1-5 \\
\hline \multirow[t]{3}{*}{ Switching cost } & The change of bank is related to seeking information about another bank. & $\mathrm{SC}_{1}$ & Likert 1-5 \\
\hline & The change of bank involves a great effort in deciding to choose another bank. & $\mathrm{SC}_{2}$ & Likert 1-5 \\
\hline & $\begin{array}{l}\text { The change of bank involves the risk of choosing another bank (that bank may not meet my } \\
\text { demands). }\end{array}$ & $\mathrm{SC}_{3}$ & Likert 1-5 \\
\hline \multirow[t]{3}{*}{ Perceived value } & The bank has a flexible pricing policy. & $\mathrm{PV}_{1}$ & Likert 1-5 \\
\hline & The bank has competitive interest rates. & $\mathrm{PV}_{2}$ & Likert 1-5 \\
\hline & The bank has a reasonable transaction fee. & $\mathrm{PV}_{3}$ & Likert 1-5 \\
\hline \multirow[t]{7}{*}{ Tangible means } & The bank has modern facilities and equipment. & $\mathrm{TM}_{1}$ & Likert 1-5 \\
\hline & The bank has a modern and easy-to-use ATM system. & $\mathrm{TM}_{2}$ & Likert 1-5 \\
\hline & The bank has convenient and large branches/ transaction offices. & $\mathrm{TM}_{3}$ & Likert 1-5 \\
\hline & The bank's products and services are diverse and suitable to market demand. & $\mathrm{TM}_{4}$ & Likert 1-5 \\
\hline & The staff's dress code is neat and impressive. & $\mathrm{TM}_{5}$ & Likert 1-5 \\
\hline & $\begin{array}{l}\text { The bank's website interface has an attractive design, easy to access; product/ service } \\
\text { brochures are eye-catching. }\end{array}$ & $\mathrm{TM}_{6}$ & Likert 1-5 \\
\hline & The bank applies modern technology in providing services to customers. & $\mathrm{TM}_{7}$ & Likert 1-5 \\
\hline \multirow{7}{*}{$\begin{array}{l}\text { Social } \\
\text { responsibility }\end{array}$} & The bank shows efforts in handling complaints and queries. & $\mathrm{SR}_{1}$ & Likert 1-5 \\
\hline & The bank complies with local laws and regulations. & $\mathrm{SR}_{2}$ & Likert $1-5$ \\
\hline & The bank complies with ethical standards. & $\mathrm{SR}_{3}$ & Likert 1-5 \\
\hline & The bank fulfills its obligations to related parties. & $\mathrm{SR}_{4}$ & Likert 1-5 \\
\hline & The bank does charity and social welfare activities; supports cultural and sports events. & $\mathrm{SR}_{5}$ & Likert 1-5 \\
\hline & The bank plays an essential role in the community. & $\mathrm{SR}_{6}$ & Likert $1-5$ \\
\hline & The bank contributes to the environmental protection campaigns. & $\mathrm{SR}_{7}$ & Likert 1-5 \\
\hline \multirow[t]{3}{*}{ Satisfaction } & I am satisfied with the bank's services. & $\mathrm{SA}_{1}$ & Likert 1-5 \\
\hline & The bank meets all my requirements. & $\mathrm{SA}_{2}$ & Likert 1-5 \\
\hline & I am satisfied with the service quality of the bank. & $\mathrm{SA}_{3}$ & Likert 1-5 \\
\hline \multirow[t]{4}{*}{ Loyalty } & I am always interested in the existence and development of the bank. & $\mathrm{LO}_{1}$ & Likert 1-5 \\
\hline & LienVietPostBank Binh Thuan is my first choice. & $\mathrm{LO}_{2}$ & Likert 1-5 \\
\hline & I will continue to use the bank's services in the future. & $\mathrm{LO}_{3}$ & Likert 1-5 \\
\hline & I will recommend the bank to my family and friends. & $\mathrm{LO}_{4}$ & Likert 1-5 \\
\hline
\end{tabular}

\section{RESEARCH METHODOLOGY}

\subsection{Analytical method}

The quantification of impacting factors to individual customers' loyalty to LienVietPostBank Binh Thuan is conducted in 3 steps. Step 1: Use Cronbach's alpha coefficient to test the correlation between observed variables. Step 2: Use exploratory factor analysis (EFA) to test the convergent and discriminant level of observed variables. Step 3: Use multivariate linear regression to test the research hypotheses.

\subsection{Data collection method}

The study uses convenience sampling to survey 450 individual customers using services at LienVietPostBank Binh Thuan. According to Hair et al. (1998), in exploratory factor analysis (EFA), the observations/measurement proportion should be $5 / 1$, meaning that 1 measurement variable requires at least 5 observations. As presented by Tabachnick and Fidell (2007), the suitable sample size for regression analysis should be $\mathrm{N} \geq 50+$ $5^{*} \mathrm{~m}$ (where $\mathrm{m}$ is the number of independent variables). Therefore, the sample size of the study meets the reliability requirement for testing the research hypothesis.

\section{RESEARCH RESULTS AND DISCUSSION}

\subsection{Test the reliability of scales}

Cronbach's alpha coefficient is used to eliminate "trash" variables. Variables with the item-total correlation coefficient less than 0.3 will be excluded (Nunnally, 1978; Peterson, 1994) and the scale is satisfactory if the Cronbach's alpha value is greater than 0.6 (Slater, 1995). The analysis result in table 2 shows that the scales have high reliability 
(min 0.840). Hence, all variables are used in the EFA stage.

\begin{tabular}{|l|l|l|}
\multicolumn{4}{|c}{ Table 2: Scale reliability test result } \\
\hline & $\begin{array}{l}\text { Number of observation } \\
\text { variables }\end{array}$ & $\begin{array}{l}\text { Cronbach's } \\
\text { alpha }\end{array}$ \\
\hline Trust & 5 & 0.909 \\
\hline Assurance & 4 & 0.941 \\
\hline Responsiveness & 6 & 0.943 \\
\hline Sympathy & 4 & 0.930 \\
\hline Switching cost & 3 & 0.880 \\
\hline Perceived value & 3 & 0.853 \\
\hline Tangible means & 7 & 0.940 \\
\hline Social responsibility & 7 & 0.935 \\
\hline Satisfaction & 3 & 0.940 \\
\hline Loyalty & 4 & 0.941 \\
\hline \multicolumn{2}{|l|}{ Source: Survey data, 2021 } \\
\hline
\end{tabular}

\subsection{Exploratory factor analysis (EFA)}

According to the EFA result for the independent variables in the research model, these values are guaranteed: The significance level of the model (Sig.) is less than 0.05 and $\mathrm{KMO}=0.824$ in the range from 0 to 1 , the factor loading values of all observed variables are greater than 0.5 . The total variance extracted reaches $78.101 \%>50 \%$. This shows that the research data is satisfactory. As a result, the analysis forms nine factors including Customer satisfaction
(SA); Sympathy (SY); Trust (TR), Assurance (AS), Responsiveness (RE), Tangible means (TM), Perceived value (PV); Switching cost (SC), and Social responsibility (SR). The observed variables belong to the factors as proposed by the model, so there is no change in the factors' names. Similarly, EFA for the dependent variable gives the following results: The significance level of the model (Sig.) is less than 0.05 and the $\mathrm{KMO}=0.876$ in the range from 0 to 1 , the factor loading values of all variables are greater than 0.5. The total variance extracted is $84 \%>50 \%$. The research data is appropriate. The analysis result forms one factor which is LO - loyalty.

\subsection{Multivariate linear regression}

Following the EFA step, multivariable linear regression analysis is used to determine factors affecting the loyalty of individual customers to LienVietPostBank Binh Thuan. The results are in table 3.

Table 3: Multivariate linear regression result
\begin{tabular}{|l|l|l|l|}
\hline Factor & Standardized coefficient & Significance level (Sig.) & Hypothesis \\
\hline Trust & 0,314 & 0.000 & H2: accepted \\
\hline Assurance & 0.311 & 0.000 & H3: accepted \\
\hline Responsiveness & 0.301 & 0.000 & H4: accepted \\
\hline Sympathy & 0.335 & 0.000 & H5: accepted \\
\hline Switching cost & 0.005 & 0.812 & H6: rejected \\
\hline Perceived value & 0.114 & 0.000 & H7: accepted \\
\hline Tangible means & 0.291 & 0.000 & H1: accepted \\
\hline Social responsibility & 0.101 & 0.000 & H8: accepted \\
\hline Satisfaction & 0.346 & 0.000 & H9: accepted \\
\hline Adjusted R ${ }^{2}$ & 0.895 & & \\
\hline Durbin-Watson stat & 1.836 & Source: Survey data, 2020 & \\
\hline Sig.F & 0.000 & \\
\hline
\end{tabular}

According to table 3 , the adjusted $\mathrm{R}^{2}$ value reaches $89.5 \%$, which proves that the loyalty of individual customers to LienVietPostBank Binh Thuan is explained by the factors in the model at a high level. Sig.F coefficient of the model is much smaller than $\alpha=5 \%$, so the regression model is significant. Durbin-Watson = 1.836 and VIF $<4$, which means that the model does not have autocorrelation and multicollinearity. The test results indicate that $8 / 9$ independent variables are statistically significant. These factors of sympathy, trust, assurance, responsiveness, perceived value, tangible means, social responsibility, and satisfaction have a positive impact on customer loyalty for LienVietPostBank Binh Thuan. In other words, if customers highly evaluate trust, responsiveness, assurance, sympathy, tangible means, perceived value, social responsibility, and customer satisfaction, their loyalty to the bank will be higher. In which, satisfaction and empathy have the 
strongest impact on the loyalty of individual customers to LienVietPostBank Binh Thuan.

\section{CONCLUSION AND IMPLICATIONS}

The study has pointed out eight factors that positively affect individual customers' loyalty to LienVietPostBank Binh Thuan, which are trust, responsiveness, assurance, sympathy, perceived value, tangible means, social responsibility, and customer satisfaction. In which, the factor of satisfaction and sympathy put the strongest influence on the loyalty of customers. Based on the research results, some managerial implications are proposed as follows: Firstly, improve service quality, and enhance customer satisfaction. Secondly, enrich the security of customer transactions. Thirdly, strengthen customer trust. Fourthly, focus on factors related to tangible means.

\section{Acknowledgement: None}

\section{Conflict of Interest: None}

\section{Source of Funding: None}

\section{REFERENCES}

1. Chaudhuri, A., \& Holbrook, M. B. (2001). The chain of effects from brand trust and brand affect to brand performance: the role of brand loyalty. Journal of Marketing, 65(2), 81-93.

2. Hair, J. F., Tatham, R. L., Anderson, R. E., \& Black, W. C. (1998). Multivariate Data Analysis $\left(5^{\text {th }}\right.$ ed.). New Jersey: PrenticeHall.

3. Nunnally, J. C. (1978). Psychometric Theory. New York: McGraw- Hill.

4. Oliver, R. L. (2000). Customer satisfaction with service. Handbook of services marketing and management, 247-254.

5. Peterson, R. A. (1994). A meta-analysis of Cronbach's coefficient alpha. Journal of consumer research, 21(2), 381-391.

6. Schultz, D. E., \& Bailey, S. E. (2000). Customer/brand loyalty in an interactive marketplace. Journal of Advertising Research, 40(3), 41-52.

7. Slater, S. F. (1995). Issues in conducting marketing strategy research. Journal of Strategic Marketing, 3(4), 257-270.

8. Tabachnick, B. G., \& Fidell, L. S. (1996). Using multivariate statistics. Northridge. Cal.: Harper Collins.

9. Yoo, B., Donthu, N., \& Lee, S. (2000). An examination of selected marketing mix elements and brand equity. Journal of the academy of marketing science, 28(2), 195211.

How to cite this article: Thai DNV, Nghi NQ. Factors impacting customer loyalty to LienVietPostBank, Binh Thuan Province. International Journal of Research and Review. 2021; 8(10): 208-212. DOI: https://doi.org/10. 52403/ijrr.20211026 